\title{
A microbiological study of neonatal conjunctivitis in two hospitals in Tehran, Iran
}

\author{
Seyed Abolfazl Afjeiee ${ }^{2}$, Sedigheh Rafiei Tabatabaei ${ }^{*}$, Fatemeh Fallah ${ }^{1}$, Arezou Tavakkoly Fard ${ }^{1}$, Farideh Shiva ${ }^{1}$, \\ Saadat Adabian ${ }^{1}$, Abdollah Karimi $^{1}$ \\ From First International Science Symposium on HIV and Infectious Diseases (HIV SCIENCE 2012) \\ Chennai, India. 20-22 January 2012
}

\section{Background}

Conjunctivitis during the neonatal period is accompanied by diffuse conjunctival injection; it is usually acquired and may result in serious eye damage. This study is to define the prevalence of neonatal conjunctivitis and to identify the causative agents of ophthalmia neonatorum in two university hospitals from 2008-2009.

\section{Methods and materials}

All neonates admitted in the neonatal department during the study period were examined for the presence of conjunctivitis. Two swab specimens containing epithelial cells of the conjunctiva were collected from newborns presenting with conjuntival inflammation. Laboratory diagnosis was based on bacterial culture and Gram staining. The isolated bacteria were identified using standard procedures. For identifying Chlamydia trachomatis we used PCR and cell culture.

\section{Results}

Of the 2253 neonates, (age range 1-30 days), clinical findings of conjunctivitis were found in 241 cases, (10.7\%). The most commonly isolated bacteria were Coagulase Negative Staphylococci, (N=130, 53.9\%); Chlamydia trachomatis was the second most common cause of acute neonatal conjunctivitis, $(n=40,16.6 \%)$. Bacterial cultures were negative in 47 neonates (19.5\%) despite clinical signs of conjunctivitis. The median age at presentation for bacterial culture positive was day 8 of life.

\footnotetext{
* Correspondence: sr_tabatabaei@yahoo.com

${ }^{1}$ Pediatric Infectious Research Center, Mofid Children Hospital, Shahid

Beheshti University of Medical Sciences, Tehran, Iran

Full list of author information is available at the end of the article
}

\section{Conclusion}

Neonatal conjunctivitis is prevalent in newborns; Gram Positive Cocci and Chlamydia trachomatis are the most common causative organisms.

\section{Author details}

${ }^{1}$ Pediatric Infectious Research Center, Mofid Children Hospital, Shahid Beheshti University of Medical Sciences, Tehran, Iran. ${ }^{2}$ Department of Neonatal Disease, Mahdieh Hospital, Shahid Beheshti University of Medical Sciences, Tehran, Iran.

Published: 4 May 2012

doi:10.1186/1471-2334-12-S1-P48

Cite this article as: Afjeiee et al.: A microbiological study of neonatal conjunctivitis in two hospitals in Tehran, Iran. BMC Infectious Diseases 2012 12(Suppl 1):P48.
Submit your next manuscript to BioMed Central and take full advantage of:

- Convenient online submission

- Thorough peer review

- No space constraints or color figure charges

- Immediate publication on acceptance

- Inclusion in PubMed, CAS, Scopus and Google Scholar

- Research which is freely available for redistribution
() Biomed Central 